International Journal of Social Science and Economic Research

ISSN: 2455-8834

Volume:06, Issue:05 "May 2021"

\title{
IMPACT OF CPTPP ON CHILD LABOUR IN VIET NAM AND THE ROLE OF SOCIAL WORK
}

\author{
Truong Thi Tam \\ Social work Faculty-Vietnam Trade Union University \\ DOI: 10.46609/IJSSER.2021.v06i05.002 URL: https://doi.org/10.46609/IJSSER.2021.v06i05.002
}

\begin{abstract}
Vietnam is known as a country that shows a strong commitment to child protection, care and education by actively participating in the Convention on the Rights of the Child. Many legal policies for disadvantaged children have been enacted and implemented. However, there is still a part of children involved in economic activities, including young workers. This situation is posing many issues about the quality of labor resources as well as ensuring social security for this group of children. Nowadays, with the global economic integration, Vietnam's participation in international trade agreements has opened up many opportunities, but it also requires us to make more efforts in solving existing social problems, including child labour. Moreover, by specifying the provisions of CPTPP agreement related to child labour, the article brings up strategic issues in the development and implementation of solutions to prevent and reduce child labour in our country, one of them is the promotion of the role of Social Work activities in this regard.
\end{abstract}

Keywords: Child labour, Social Work, CPTPP

\section{Introduction}

Article 1 of the United Nations Convention on the Rights of the Child 1989 (CRC) and Article 2 of ILO Convention 182 on the Elimination of the Worst Forms of Child Labor 1999 (Convention 182) define:"Children who are under 18 years of age". But it depends on each nation, CRD allow member countries to be able to specify a lower range of age. In Vietnam, the definition of children is clearly stated in the Law on Children (2016)and is defined as "being under 16 years of age".

The concept of "child labour" is when children participating in labor in accordance with the law and labor activities that hinder or negatively affect the development of their physical, intellectual, personality and comprehensive development. It is different from the term "children 


\section{International Journal of Social Science and Economic Research}

ISSN: $2455-8834$

Volume:06, Issue:05 "May 2021"

participating in labor"(also known as children participating in economic activities), refer to children (5 -17 years old) participating in production - business - service activities, i.e. manufacturing for consumption or for sale, paid or under-paid, occasionally or frequently, legal or illegal work but works at least an hour (1 hour) on any day of the week[2]Stem from the characteristics of the economy in Vietnam and some other countries in the region, when the household economy still accounts for a large proportion of the national economy, the appropriate participation of children in family economic activities is considered an opportunity to help them learn, experience and raise their sense of responsibility to their families and society. However, the problem here is that supervision and management should be carried out effectively to avoid the abuse of labor and become child labour. When considering whether a case is child labour, it is based on three factors: (1) Does the work which the child participate in have a negative effect on their physical, mental and moral development? (2) Are working conditions heavy, toxic and dangerous? (3) Is the working time suitable for the age prescribed by law? [3].

Vietnam is the first country in Asia and the second country in the world ratify the United Nations Convention on the Rights of the Child. Specifically for child labour, in order to express its commitments, Vietnam has ratified two relevant International Labour Organization(ILO) Fundamental Conventions including the Minimum Age Convention (Convention 138, 1973) and the Worst Forms of Child Labour (Convention 182, 1999). At the same time, the Government has amended and supplemented legal documents, promulgated national policies and action programs to address child labour. With these efforts, in recent years the problem of child labour has been basically solved effectively. The number of child labour decreased from 1.75 million (in 2012) to $9.6 \%$ of the 5-17years old children's population to $1,031,944$ (in 2018) accounting for $5.4 \%$ of the population of children aged 5-17[1, 2]. However, this problem has persisted so far, transforming in many different forms, more difficult to detect, making it difficult to supervise and manage for the authorities. These are new challenges for Vietnam in the face of the task of eliminating child labor in all its forms, especially in the current context of international integration.

As of December 2018, Vietnam has signed 12 free trade agreements (FTAs) and is in the process of negotiating to sign three other FTAs. Among the FTAs signed and under negotiation, CPTPP and EVFTA are the first two new generation free trade agreements Vietnam has signed that binds the issue of abolishing child labour in trade [2,tr.5]. Accordingly, member countries participating in these Agreements are committed to "effectively abolishing child labour" and "prohibiting the worst forms of child labour". With those provisions, it is necessary for the Government of Vietnam to make more efforts in implementing solutions to solve this problem. In order to do that, many agencies, departments, branches and social organizations are required to collaborate especially social work. 


\section{Methodology}

The author uses the method of synthesizing and analyzing the sub-document in the results of the national investigation on child labour in Viet Nam (in 2012 and 2018); academic articles at the international workshop on Social Work with Child Labour; articles, press release, project documents ... posted on the ILO website in the "child labour" directory; articles from the search results with the keywords: "CPTPP agreement and child labour", "Social work with child labour" through the search engine on the website:

https://www.google.com;https://scholar.google.com

\section{Result}

\section{Current situation of child labour in Vietnam}

According to the 2018 National Child Labour Report, there were 19,254,271 children aged 5-17 (20.3\% of the total population), $52.1 \%$ of which were boys and $47.9 \%$ were girls. Specifically, if divided by age, $66 \%$ of 5-12 years old, $13.9 \%$ from 13-14 years old and the remaining $20.1 \%$ in the 15-17 age group. The number of children living in urban areas is $32 \%$. The number of children participating in economic activities (also known as working children, children participating in labor) is $1,754,066$ children (accounting for $9.1 \%$ of the total number of children aged 5-17 in the country). Of the children participating in economic activity, 1,031,944 were identified as child labour (accounting for $5.4 \%$ of the country's total 5-17yearolds, accounting for $58.8 \%$ of the children participating in economic activity). Comparing to the results from the 2012 child labour census, the proportion of child labour has tended to decrease significantly.

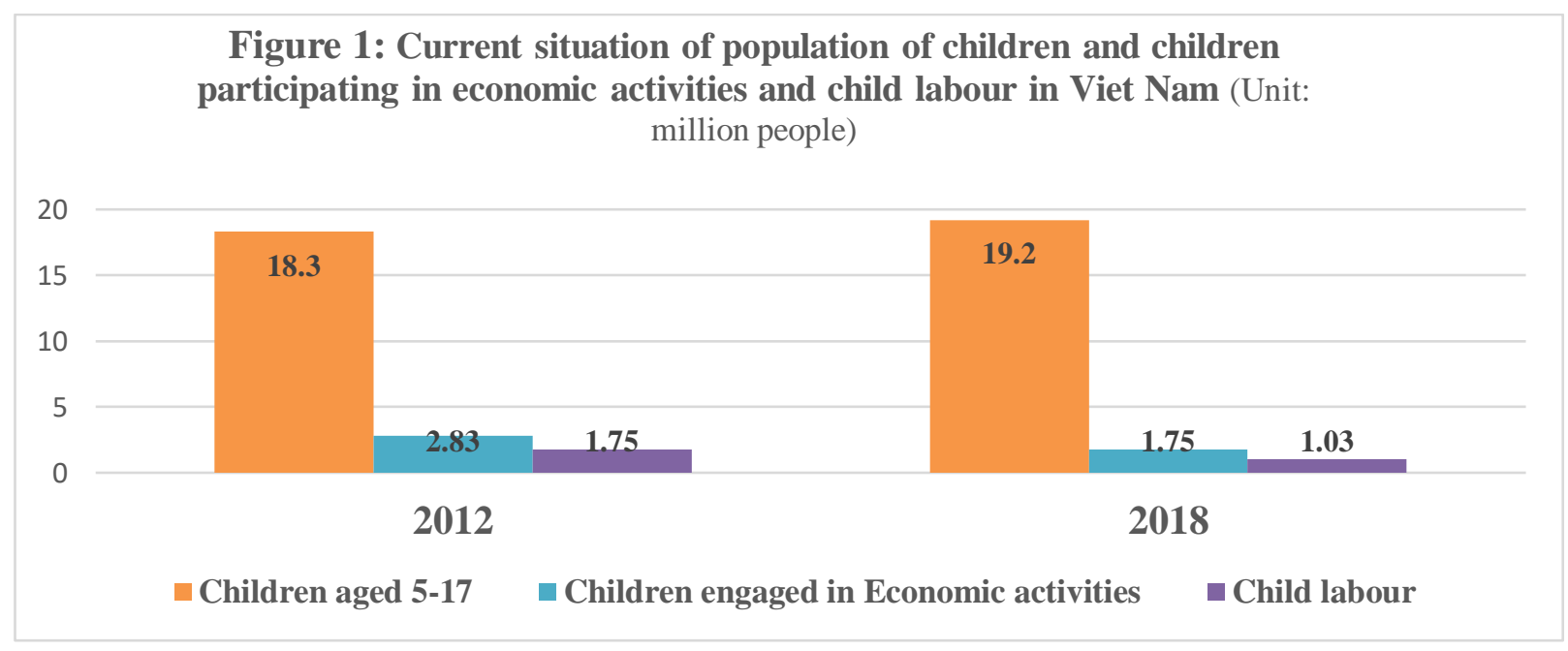

(Source: Aggregated results from the 2012 and 2018 National Labour Report) 
International Journal of Social Science and Economic Research

ISSN: 2455-8834

Volume:06, Issue:05 "May 2021"

Structurally, the majority of children engaged in economic activities, child labour and child labour engaged in dangerously toxic hard work as boys (accounting for $54.5 \%$ of children engaged in economic activities, 59\% in the child labour group and $67.2 \%$ in the labour group participating in hazardous toxic hard work). There were $51.2 \%$ of child labourages of $15-17$ and $84 \%$ of child labour distributed in rural areas.

Table 1: Situation of child labour by gender, age and type of work

\begin{tabular}{|l|c|c|c|c|c|c|c|}
\hline \multicolumn{1}{|c|}{ Type of work } & Amount & Percent & \multicolumn{2}{|c|}{ Gender } & \multicolumn{3}{c|}{ Age group } \\
\hline \multicolumn{1}{|c|}{ Unit } & person & $\%$ & $\%$ & $\%$ & $\%$ & $\%$ & $\%$ \\
\hline \multicolumn{1}{|c|}{ Nationally } & $\mathbf{1 . 0 3 1 . 9 4 4}$ & $\mathbf{1 0 0 . 0}$ & $\mathbf{5 9 . 0}$ & $\mathbf{4 1 . 0}$ & $\mathbf{3 0 . 8}$ & $\mathbf{1 8 . 0}$ & $\mathbf{5 1 . 2}$ \\
\hline Paid workers & 327.624 & 31.7 & 66.2 & 33.8 & 3.5 & 15.0 & 81.5 \\
\hline $\begin{array}{l}\text { Auto-production, self- } \\
\text { consumption }\end{array}$ & 198.505 & 19.2 & 47.6 & 52.4 & 56.5 & 21.7 & 21.8 \\
\hline $\begin{array}{l}\text { Labor in family and } \\
\text { other forms }\end{array}$ & 445.162 & 43.2 & 58.9 & 41.1 & 39.1 & 18.5 & 42.4 \\
\hline Unknown & 60.653 & 5.9 & 58.2 & 41.8 & 32.0 & 18.4 & 49.6 \\
\hline \multicolumn{3}{|c|}{ Source: 2018 National Child Labour Census) } & {$[2, p .32]$} \\
\hline
\end{tabular}

Regarding the economic sector, the 2018 census showed that children engaged in labor in all three economic areas were agriculture (53.6\%), industry - construction (23.7\%) and services (20.8\%), an undetermined rate (1.9\%) with 89 specific jobs with child labour involved (there are 24 main jobs attracting $85.6 \%$ of the total child labour). Comparing this result with 2012, there was a slight shift in child labour between economic sectors with a decrease in the agricultural sector and an increase in the industrial - construction and service sectors.

Figure 2: Child labour structure by economic sector (Unit: \%)

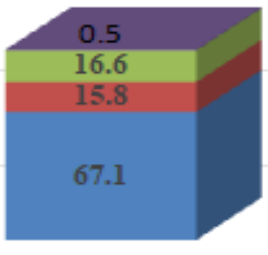

2012

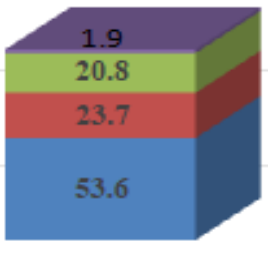

2018

- Agriculture Industry-Construction $\quad$ Service $\square$ Unknown

(Source: Aggregated results from the 2012 and 2018 National Labour Report) 
International Journal of Social Science and Economic Research

ISSN: 2455-8834

Volume:06, Issue:05 "May 2021"

In terms of working time, an estimated $34.2 \%$ of child labour working 40 hours per week or more are concentrated mainly in the 15-17 age group (accounting for 57.7\%) and there is not much difference between boys and girls. But it is worth noting that $12 \%$ of children under the age of 15 have been working more than 40 hours a week. This is an inappropriate working time, which has a negative effect on the comprehensive and long-term development of children, especially for children under 15 years of age. This issueneeds strengthened intervention and prevention in the near future. The common working age of child labour is 12 years or older. However, $10.3 \%$ of workers started working under the age of 10 and 3.5\% started from 5-7 years old. This is a young age to be able to participate in labor when their physical, mental and mental development is still limited.

\section{Figure 3: Working age of child labour (Unit: \%)}

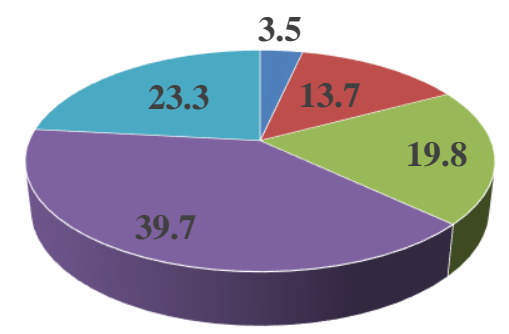

- 5-7 years old - 8-10 years old $\quad$ 11-13 years old - 14-17 years old $\quad$ Unknown

(Source: Aggregated results from the 2018 National Labour Report)

In terms of average income per month, only 296,534 children $(28.7 \%)$ out of a total of 1,031,944 child labour that determine their average monthly income, the rest of them have difficulty in this. Based on the average income of the children identified, the popularity of child labour is 2.5 million VND/month or more and mainly for children between the ages of 15-17.

Notably, the results of the 2018 child labour census also showed that there were $\mathbf{5 1 9 , 8 0 5}$ children aged 5-17 who identified as child labour doing hard work, toxic and dangerous (accounting for $2.7 \%$ of the total number of children aged 5-17 years, accounting for $29.6 \%$ of the children engaged in economic activity and accounting for nearly $50.4 \%$ of the total child labour). Of those, nearly $67.2 \%$ were boys and nearly $32.8 \%$ were girls. This is the group of children most at risk of injury in the child labour group, which should be given priority to intervene and abolish in accordance with the provisions of ILO conventions and the provisions committed in the signed trade agreements. Therefore, in upcoming action programs to address the child labour, Vietnam needs to focus on effective solutions towards this group of children first. However, in the process 


\section{International Journal of Social Science and Economic Research}

ISSN: $2455-8834$

Volume:06, Issue:05 "May 2021"

of developing plans, there are two points need to be considered which were reflected in the results of the 2018 child labour investigation:

- Although the proportion of child labour in rural areas is higher than in urban areas, out of a total of 870,323 child labour in rural areas only $48.8 \%$ of children do dangerous toxic hard work. Meanwhile, the proportion in urban areas was 58.8\% out of 161,621 child labour. This figure shows that although the size of urban labour is less, the level and dangerous work of urban labour is higher than in rural areas.

- Estimates from the investigation show that $47 \%$ of child labours doing dangerous toxic hard work receive wages, $5 \%$ belong to the types of self-employment, self-consumption and it is worth mentioning that up to $43 \%$ of child labours do dangerous toxic heavy jobs of the household economy. This number changes the previous notion that child labour is at risk of doing dangerously toxic heavy work that only occurs in the group of children in wage employment.

Learning about the root causes of labour participation, the data of the investigation showed that the two most selected reasons were to generate income for the family $(20.7 \%)$ and want to participate in production and business of households $(27.3 \%)$, followed by the cause of making income for themselves $(9.3 \%)$ and due to not going to school $(6.7 \%)$.

\section{Addressing Childlabour and the impact of CPTPPA agreement.}

Over the years, with support from international organizations such as the ILO, UNICEF, Child Fund, World Vision, Plan Save Children, The Government of Vietnam has implemented a number of syncary solutions to prevent and initially reduce child labour across the country such as: [13]

- Amending, supplementing and finalizing the relevant legal framework on child protection, prevention and intervention in child labour settlement: Article 37 of the 2013 Constitution prohibits the abuse, torture, mistreatment, neglect, abuse and exploitation of labor and other acts of violation of children's rights; Section 1 - Chapter XI of the 2012 Labor Code detailing minor workers; Article 4 - The Law on Children 2016 states that the arrest of working children in violation of the provisions of the labor law is an act of child exploitation and is strictly prohibited by law, Article 10 also determines that exploited children are among the groups of disadvantaged children in need of protection and assistance. There are also other relevant laws such as the Law on Handling administrative violations 2012, the Civil Procedure Code 2015. 


\section{International Journal of Social Science and Economic Research}

ISSN: $2455-8834$

Volume:06, Issue:05 "May 2021"

- Developing, promulgating and implementing national action programs: National Action Program on Children(2001-2010, 2010-2020) with integration of objectives on prevention and reduction of child labour; Program on prevention of street children, sexually abused children and working children in hazardous and dangerous heavy conditions (2004-2010); Child Labour Prevention and Mitigation Program (2016-2020), National Child Protection Program (20112015, 2016-2020).

- Cooperate with international organizations, NGOs, social organizations in the country to develop and implement projects and models to support child labour, families and communities with child labour: with many activities such as: direct intervention for at-risk children, who have been or are child labour (detecting and taking children out of a hard, toxic, dangerous working environment; supporting the improvement of working conditions; counseling, vocational training, vocational transformation for child labour.; supporting access to health services, education; psychological support; awareness-raising communication...); Activities to support the development of livelihoods for at-risk families, who have or are having child labour (loan support; vocational training, job creation for young parents; improving occupational safety and hygiene conditions in household households; awareness communication; consulting, connecting raw materials or product outputs...); Media activities to raise public awareness $[6,13]$.

The implementations have shown the Government of Vietnam's efforts and determination to implement its commitments in the implementation of Convention 138 and ILO Convention 182. Initial results have helped reduce the number of child labour from 1.75 million (2012) to 1.03 million (2018). However, the remaining number still creates many challenges for us, especially when Vietnam has join the signing of free trade agreements (FTA) with accompanying provisions related to elimination of child labour. Specifically, chapter 19 of the CPTPP provides labor provisions for member countries, including two points regarding LABOUR as follows: ${ }^{1}$

- Article 19.3 (c): effective elimination of child labour and this Agreement prohibits the worst forms of child labour.

- Article 19.6: Each Party recognizes the objective of ending all forms of forced labor, including child labour. The Parties are obliged to do so in accordance with Article 19.3 (Labor Rights),each party should take appropriate initiatives to prevent the importation of goods from sources where the production process is in whole or in part using forced or compulsory labor, including child labour.

${ }^{1}$ http://cptpp.moit.gov.vn/data/e0593b3b-82bf-4956-9721-88e51bd099e6/userfiles/files/19\%20\%20Chuong\%20Lao\%20dong\%20-\%20VIE.pdf 


\section{International Journal of Social Science and Economic Research}

ISSN: $2455-8834$

Volume:06, Issue:05 "May 2021"

These provisions have created new challenges for the prevention, mitigation and eradicating of child labour in Viet Nam:

- The completion of the legal framework on child labour: One of the important issues brought up in the last round of negotiations before the signing of CPTPP is the labor right, in order to help workers and businesses are entitled the benefits in a fair and sustainable way in the working environment. The CTTPP requires all Member Statesto pass and uphold the labour rights set out in the 1998 Declaration of the International Labour Organization (ILO) with 8 basic conventions on fundamental principles and rights at work(Conventions 87 and 98 on freedom of union and collective negotiation; Conventions No. 29 and 105 on the a total eradication of forced and compulsory labour; Conventions 138 and 182 on the a total eradicating of child labour; Conventions 100 and 111 on the eradication of employment and professional discrimination).Up to now, Vietnam has not ratified three Conventions 87, 98 and 105.Therefore, achieving this requires Vietnam to develop, amend and complete the relevant legal framework. However, the completion of the legal framework in the management and settlement of child labour violations in our country still has many shortcomings:

+ The definition of child labour has not been given in a unified way in the relevant legal documents, making it difficult to identify and review child labour in reality. The Children's Law (2016) does not explicitly mention the prohibition of forcing children to participate in heavy, toxic work. Article 26 of this law only provides that children have the right to be protected from labor exploitation[11]. Thus, this new law has not made a breakthrough in dealing with and deterring cases of coercion and abuse of child labour for economic benefits. In addition, the sanctions for handling violations specified in other legal documents have not been compatible, including the Labor Code (2019)[10].

+ The use of child labour takes place mainly in the unofficial economic sector, common in household economic forms - where the supervision system of the labor in spectorat or has not yet played its role due to the inspection process and procedures prescribed in the current Inspection Law can only be applied in the official economic sector, while in the unofficial economic areas that have not yet been prescribed and guided [12]. Besides, industrial relations in this area have not significantly reduced the effectiveness of intervention by the trade union organization at the establishment in monitoring and intervening in this regard[19].

+ Sanctioning in cases where violations related to child labour are not strong enough, insufficient deterrence, the system of standards to measure the extent of harm of children when they are child labour has not yet made, hence, the supplement and amendment of sanctions lack the necessary grounds [13]. 


\section{International Journal of Social Science and Economic Research}

ISSN: 2455-8834

Volume:06, Issue:05 "May 2021"

- Termination of child labourin the supply chain: In the context of globalization and the impact of CPTPP agreement, the supply chain in production is expanding and more complicated with the participation of many components in the production process, making it more difficult to control, manage and prevent the use of child labour in this process. Child labour is not only strictly prohibited at the stage of direct production of products but also at all relevant stages from the supply of input materials to the process of transporting and distributing goods ... [16] Violating these regulations will have a great impact on the consumption of products, especially for exported products, affecting Vietnam's reputation in the international market. Meanwhile, to achieve this goal, we are also facing many challenges

+ Many of our export items such as seafood processing, agricultural products, exported crafts, garments ... are concentrated largely in the non-official economic sector, household production, small business households - where there is an exists of risk in the use of child labour. While the applicable level of the legal framework as well as the management, inspection and supervision of this area still have many holes. This is considered a huge challenge to the requirements of the eradicating of the use of child labourin the supply chain as well as the investigation of the origin of the exported products that we have signed in CPTPP.

+ The level of awareness of children themselves, their families, employers, labor brokers and communities about the supply chain and the prohibition of the use of child labour in supply chain in accordance with international regulations are still limited.

- Efficiency and sustainability in solutions: CPTPP requires member countries to commit to effectively eliminate child labour in practice. In order to do that, we need to overcome the disadvantages that reduce the effectiveness of the solutions that have been implemented in the past.

+ Lack of resources: From the experience of solving childlabour problems of many countries in the world and the practice of implementing solutions in Vietnam in recent years, to solve this problem effectively and sustainably, it requires the implementation of overall solutions with the participation of many departments, branches and social organizations. It means, solving the problem of childlabour needs to be done in parallel with other related issues such as poverty alleviation, development of household livelihoods; to innovate and improve the quality of education; raising public awareness; developing social work services network, protecting children, etc. However, to deploy that synchronization, it takes time and resources (finance and manpower) - two factors we are lacking and weak. Funding for the implementation of programs and models in the prevention and mitigation of childlabour is limited from central to local level. The current practice shows that some localities do not allocate or allocate too little funding, 


\section{International Journal of Social Science and Economic Research}

ISSN: $2455-8834$

Volume:06, Issue:05 "May 2021"

making it difficult to carry out[16]. The main resources involved in implementing interventions with childlabour such as labour inspectors, child protection officers at the local level, social workers ... is small in number and limited in professional capacity[9]. The coordination between the parties is also formalistic, not really recognized as a common task to be addressed. In fact, many localities still see this as the employment of social workers, while at the baseline such as the commune, the social workers must be in charge of many related fields at the same time, the local collaborators work many jobs at the same time affecting the effectiveness of activities of detecting, supervising and interfering in labor cases.

+ The way the solution is implemented is still inadequate: In fact, observations show that for the current problem of child labour in Vietnam, there are parties including governments, international organizations in Viet Nam (ILO, UNICEF...) and some NGOs (Blue Dragon) participating in intervention and resolution. However, the way solutions are implemented also varies from region to region. From a state management perspective, the way to organize interventions with child labour is often seen as the Department of Labour, Invalids and Social Affairs (MOLISA) in collaboration with local authorities to make a list of disadvantaged children who have been or are working as child labour to provide material support. This makes it difficult for a section of child labour when they do not live with their families but work and live in other local host families, or in the case of child labour but not in poor households or near-poor households[3].For interventions from international organizations, NGOs are often implemented through projects with more practical support activities, significant results but limited implementation area and project implementation time. In fact, in many localities after the project is finished, the funding is no longer available, the maintenance and preservation of intervention results is limited.

+ The statistics and review of child labour in the report are not up-to-date, not close to reality. Child labour is now measured by a synthesis of data from local reports. But in the reality, this practice is not suitable for child labour groups with movement, migration to other places of work or with wandering children who make a living on the streets - a particular type of child labour.

+ Prevention and mitigation of child labour in the context of covid-19 epidemic: The epidemic that causes poverty can increase pushes families to use all means to survive, including accepting children to work not in accordance with the law, especially in the non-official economic sector, the economic form of self-reproduction, self-consumption or small business households. Due to the effects of the epidemic, many children have to pause their studying, switch to distance learning, but difficult families cannot provide the right means for online learning to disrupt learning or affect the quality of their lessons. For children engaged in economic activities, there is a risk of having to work more time, even with a heavier type of work. Researching some 
International Journal of Social Science and Economic Research

ISSN: 2455-8834

Volume:06, Issue:05 "May 2021"

countries show that, as poverty increases by $1 \%$, child labour will increase by at least $0.7 \%$ [21]. Meanwhile, the implementation of social distancing to ensure epidemic prevention makes it more difficult for local authorities to monitor and detect the use of child labour.

\section{Social work activities in the prevention and reduction of child labour}

Child protection is one of the top priority areas and tasks of Social Work, especially for disadvantaged children such as child labour. With four basic functions: prevention, therapy, recovery and development, Social work focuses on two main groups of activities including: (1) Preventive activities for children at risk of becoming child labour and (2) Interventions and support activities for the group of children who have been or are on child labour[3, 13, 14, 17, $18]$.

Social work in childlabour prevention focuses mainly on the following activities:

- Communication to raise awareness for children, especially the group of children engaged in economic activities- the high-risk subjects become child labour with knowledge about children's rights, the provisions of the law on child labour, the consequences of child labour etc. in various forms such as coordinating the organization of communication in schools integrated in the first meeting of the week, through the organization of learning contests, performing arts activities, media products etc. Communication to raise awareness for families of children and communities with child labour about the provisions of law and responsibilities of families and communities in preventing and abolishing child labourthrough loudspeakers, televisions, newspapers, leaflets, pans, slogans etc.

- Support in education and development of life skills for at-risk children (disadvantaged children, children engaged in economic activities): carry out social work insurance activities in schools to support tuition fee exemption, support school supplies, connect resources to support vehicles to school, supporting new admission procedures, back-to-school procedures for students who have had their learning interrupted; Consulting and providing career guidance to connect to vocational training establishments for those who have finished secondary school and need to go to vocational training; Supporting the development of life skills, skills to prevent coercion, labor exploitation, prevention of sexual abuse through social work in group insurance activities or integrating with activities social work in school.

- Connecting and supporting livelihood improvement for disadvantaged families and families with children at risk of becoming child labour through activities such as: Supporting access to loans; Connect to vocational training institutions, find jobs for parents/caregivers of children; 


\section{International Journal of Social Science and Economic Research}

ISSN: $2455-8834$

Volume:06, Issue:05 "May 2021"

Providing knowledge, technical advice, improving production conditions; Emergency relief in cash or in-use (seedlings, crops, production tools...)

- Mobilizing policies, contributing opinions to formulate, amend and finalize the legal framework on child labour in Vietnam.

Social work in intervention and support for children who are child labour:

- Participate in monitoring, detecting, receiving and handling child labour cases in the area according to the emergency intervention process if necessary.

- Implement case management, connect or directly implement intensive support activities for child labour: Medical care support; Psychological counseling; Provide alternative care (in social protection centers, shelters etc.) in cases where it is necessary to ensure safety, temporary isolation from risk factors for injury to children; Legal defense and assistance to protect the legitimate interests of children before related parties; Supporting education, propagating awareness raising, life skills development; Repatriating support for childlabour wandering for a living, being herded or trafficked; Supporting community integration for child labour after intervention.

\section{Discussions}

Child labour's situation in Viet Nam has improved significantly with the reduction in the size of child labour, but with the remaining 1.03 million along with the requirements set out by free trade agreements, we need to increase the implementation of more practical solutions to solve this problem. In order to do that, first of all, we need to recognize and solve the shortcomings that are hindering the effectiveness of the programs and measures that have been implemented in the past.

As a pioneer, social work activities in the future need to promote more of their role in solving child labour problems. Some proposals and suggestions set out in the development and implementation of social work insurance activities in the prevention and intervention with childlabour are as follows:

- Awareness communication has been always considered as an effective measure in the prevention of childlabour. In addition to continuing to maintain the edict communication content, in the coming time, it is necessary to add more information to raise awareness about the supply chain, the importance of the eradication of childlabour in the supply chain in the context of economic integration for small business households, trade villages and business enterprises in the 


\section{International Journal of Social Science and Economic Research}

ISSN: $2455-8834$

Volume:06, Issue:05 "May 2021"

non-official economic sector. It is necessary to help employers recognize the responsibility of the business, because no one can replace the business in overseeing the entire production process, subcontractors and its entire supply chain. If the enterprise does not strictly implement, it will face the risk of violating the standards of progressive trade agreements, directly affecting the market share and prestige of the enterprise itself and more broadly the interests of the whole country.

In terms of media and forms of communication, it is also necessary to add and choose new forms to improve efficiency such as internet communication, fan page, messages etc. Combining the broad spectrum goal by mass media with in-depth communication according to the group and club model with the choice of media content suitable for each group of subjects. Communication activities need to take place more frequently by building and expanding the network of local media collaborators in schools, communities, groups and clubs.

- Continue to maintain social work insurance activities in schools with support for education and development of life skills in order to achieve the goal of childcare in schools. In particular, in addition to material support, it is necessary to pay attention to the pilot implementation of selfhelp group models, clubs to support children who need additional knowledge. Not only by integrating life skills in schools, but more seminar groups can be organized for high-risk children in the community, providing reliable phone numbers and addresses for children so they can contact them when urgent intervention is needed.

- In term of advocacy and completion of the legal framework on child labour, attention should be paid to the contents of clearer regulations on the position and role of social workers in supporting this group of children, in order to create a full legal basis for the interventions of social workers at the facility.

- Develop networks and regularly train and improve professional capacity for social workers at the baseline to promote the role of social workers to participate in the supervision and detection of childlabour in the community. Coordinate with local authorities to collect information and make a list of child labour including: children engaged in economic activities, children at risk of becoming child labour, children who have been or are working in the area, including immigrant cases. Social workers grasp and assess the needs of children and their families for timely proposals and interventions.

- For intensive interventions, it is necessary to invest in building and developing a professional social work insurance service system with a clear and specialized intervention process for child labour and training these processes to the social workers, collaborators and individuals, relevant organizations in the area. Coordinate and participate with international organizations and NGOs 


\section{International Journal of Social Science and Economic Research}

ISSN: $2455-8834$

Volume:06, Issue:05 "May 2021"

to implement intervention projects in the area. Implementing and organizing the maintenance of results from the project and the expansion of successful models, programs and solutions in the prevention and mitigation of child labour.

\section{Conclusion}

It can be seen that with the Government's intervention efforts, the issue of child labour in Vietnam has changed positively over the years. Participation in CPTPP agreement opens up development opportunities in all aspects, and also sets challenges in solving the childlabour problem. However, it should also be recognized that these are positive challenges that motivate us to make more efforts, more determination in prevention and mitigation towards the eradicating of child labour. Therefore, it is necessary to determine that child labour is no longer merely a matter of children's rights, it is a matter related to the socio-economic development of the country, the prestige and position of the nation in the international arena.

Solving the problem of child labour is the responsibility of state management agencies, businesses and consumers. With state management agencies, social work activities are considered as tools to help the state implement social security and child protection activities, including the child labour group. This is a task that the social work insurance industry must undertake and be responsible for completing. In the context of the development of social work insurance industry in Vietnam is still young as today, to achieve this goal, social work insurance will have to overcome many difficulties and challenges. However, this is also considered as an opportunity to help social work enterprises affirm their position and role in the community and society.

\section{References}

1. MoLISA, General Statistics Office, ILO, 2012 National ChildLabour Census

2. MoLISA, General Statistics Office, ILO, 2018 National Child Labour Census

3. Duong Thi Thu Huong (2018), Child Labour and the issue of strategies and models of support for child labour in Viet Namtoday, International Conference Yearinth: Social Work Services for Child and Child Labour who have been trafficking, abuse, Labour - Social Work, 2018. ISBN: 978-604-65-3274-3

4. Constitution of Vietnam (2013)

5. Comprehensive and Progressive Agreement for Trans-Pacific Partnership (CPTPP) 


\section{International Journal of Social Science and Economic Research}

ISSN: $2455-8834$

Volume:06, Issue:05 "May 2021"

6. https://www.ilo.org/hanoi/Areasofwork/child-labour/lang--vi/index.htm

7. ILO (1973), Convention 138, Minimum Working Age Regulation

8. ILO (1999), Convention 182, Prohibition and Urgent Action to Abolish The Worst Forms of Child Labour

9. Le Thi Hoang Lieu (2018), Minor Labour-Victims of SexualAbuse, International Conference Yearinar: Social Work Services for Child and Child Labour, Trafficking, Labour - Social Work, 2018. ISBN: 978-604-65-3274-3

10. Viet Nam Labour Law (2019)

11. Viet Nam Children's Law (2016)

12. Nguyen Dang Doanh (2019), Strengtheningsupervision inspection in the prevention of child labourreduction, Online Social Labor Magazine, October 15, 2019.

13. Nguyen Hai Huu (2018), Overview of the situation and policies for child and child labour who have been traded,abused, the International Conference Yearbook: Social Work Services with child and child labour who have beentraded, abused, labor and social workers, 2018. ISBN: 978-604-65-3274-3

14. Nguyen Kim Loan (2018), EarlyLabour Children's Issue and Social WorkApproach, International Workshop Yearinth: Social Work Services for Child and Child Labour, Trafficking, Labour - Social Work, 2018. ISBN: 978-604-65-3274-3

15. Nguyen Thi Lien (2018), From the situation to the model of supporting early working orphans in ThuongCuи commune, Tan Son district, PhuTho province, The international conference: Social work services for child and child labor who have been trafficked,abused, labor and social workers, 2018. ISBN: 978-604-65-3274-3

16. Nguyen Thi Nga (2020), Reducing Child Labour: Practical ActionIsNeeded, Party Building Magazine, June 16, 2020

17. Nguyen Thi Thai - Ma Dieu Linh (2018), Overview of social work services with early working children and trafficking; International Conference Year: Social Work Services for Child and Child Labour, Trafficking, Labour and Social Work, 2018. ISBN: 978-604-653274-3

18. Nguyen Thu Ha and his associates (2018), Children working in Viet Nam: Portraits and proposals of social workactivities, International Workshop Yearinth: Social work services 
International Journal of Social Science and Economic Research

ISSN: 2455-8834

Volume:06, Issue:05 "May 2021"

for child and child labour who have been trafficking, abuse, labour and social workers, 2018. ISBN: 978-604-65-3274-3

19. Nguyen Xuan Thai (2018), CPTPP opportunities -challenges for workers and Trade Unions of Vietnam, website of the Ministry of Industry andTrade on November 28, 2018.

20. UNICEF (1990), United Nations Convention on the Rights of the Child

21. Xuan Anh (2020), Responding to the risk of increasing child labour due to Covid19,People'sDaily, June 12, 2020. 